\section{Effects of Mowing and Trinexapac-Ethyl on St. Augustinegrass Sod Establishment during a Simulated Water Variance Period}

\author{
Daniel Hargey ${ }^{1}$, Benjamin Wherley ${ }^{1,3}$, Andrew Malis ${ }^{1}$, \\ James Thomas ${ }^{1}$, and Ambika Chandra ${ }^{2}$
}

ADDitionAl INDEX wORDs. root length, root weight, root development, root extension, mowing height and frequency, plant growth regulator, water restrictions

SuMmary. During water conservation periods, municipal water purveyors often limit irrigation for established lawns to once every 7 to 14 days, although a 4- to 6-week variance to these restrictions is often permitted for turfgrass establishment. Therefore, establishment practices promoting rapid development of a deep and expansive root system during this time may support long-term success of the turf once irrigation is scaled back. Sod producers and turf managers could benefit from information on the influence of mowing practices and plant growth regulator (PGR) applications on turf root development during this initial establishment period. The objectives of this greenhouse study were to 1 ) evaluate the effects of mowing and trinexapac-ethyl (TE) application on final turf quality and root development characteristics (weight, total length, and extension rate) of st. augustinegrass (Stenotaphrum secundatum) sod during a 35-day establishment period, and 2) compare the quality and rooting potential of 'TamStar', a newly released, embryo-rescue-derived cultivar possessing good drought resistance, with 'Floratam', the current industry standard for drought resistance. Weekly mowing reduced both total $(2.5$ to $90 \mathrm{~cm})$ and deep $(45$ to $90 \mathrm{~cm})$ root weight and root length in both cultivars. TE had no effect on visual quality of 'TamStar', but decreased turf quality in 'Floratam'. TE reduced clipping yields of both cultivars but did not improve root development for either cultivar. Depth of maximal root extension during establishment was unaffected by cultivar, mowing, or TE treatment. At the conclusion of the 35-day establishment period, 'TamStar' exhibited superior turf quality and root weight relative to 'Floratam', but also produced higher rates of shoot growth. Results emphasize the importance of withholding mowing during st. augustinegrass establishment, particularly for improving total root length and deep root production, and also show that TE does not improve root development of st. augustinegrass during establishment.

$\mathrm{B}$ ecause of recurring drought and increased demands for potable water throughout the United States, municipalities are enacting landscape irrigation restrictions to conserve water. Homeowners and turf managers are often the first to be affected by restrictions on landscape irrigation. Commonly, these restrictions include a variance period of $\approx 35 \mathrm{~d}$ postplanting, during which the homeowner or turf manager may

This research was supported in part by Texas A\&M AgriLife Research.

This research was conducted as a portion of the senior author's (Daniel Hargey) thesis requirement for completion of his MS degree.

${ }^{1}$ Department of Soil and Crop Sciences, Texas A\&M University, 2474 TAMU, 370 Olsen Boulevard, College Station, TX 77843

${ }^{2}$ Texas A\&M AgriLife Research, 17360 Coit Road, Dallas, TX 75252

${ }^{3}$ Corresponding author. E-mail: b-wherley@tamu. edu. water as needed to facilitate establishment (San Antonio Water System, 2015; Southwest Florida Water Management District, 2015). During this time, establishment practices promoting rapid development of a deep and expansive root system may help ensure long-term success of the turf as irrigation is scaled back.

Within Texas and across the southeastern United States, st. augustinegrass is a predominant warm-season turfgrass used for lawns because of its ability to withstand heat and tolerance to shade (Duble, 2013). St. augustinegrass cultivar Floratam is widely used throughout the southeastern United States for home lawns because of its good drought resistance (Duble, 2013; Siefers and Beard, 1999). Steinke et al. (2010) reported that 'Floratam' exhibited significantly delayed leaf firing as well as superior turfgrass quality and green groundcover relative to other st. augustinegrass cultivars during a 60-d drought in San Antonio, TX. In the same study, 'Floratam' also demonstrated superior recovery attributes as compared with other cultivars following resumption of irrigation.

Genetic variation in st. augustinegrass manifests in morphology, adaptability, and stress tolerance (Busey 2003; Chandra et al., 2015). Such genetic variation is observed to be partitioned between ploidy levels. Diploids tend to exhibit superior turfgrass quality because of their finer leaf texture, bright green color, and compact growing habits, whereas polyploids such as 'Floratam' have been shown to exhibit increased resistance to insects, diseases, and drought stress (Busey, 1986, 2003). Genovesi et al. (2009) reported the use of embryorescue technique to develop interploid hybrids between polyploid and diploid germplasm of st. augustinegrass to facilitate gene exchange between different ploidy levels. 'TamStar' (formerly tested under the experimental name DALSA0605), is the first and only reported embryo-rescue-derived interploid cultivar of st. augustinegrass and was recently released by Texas A\&M AgriLife Research (Chandra et al., 2015).

Much of the research involving rooting and drought resistance in

\begin{tabular}{llll}
\hline $\begin{array}{l}\text { Units } \\
\text { To convert U.S. to SI, } \\
\text { multiply by }\end{array}$ & U.S. unit & SI unit & $\begin{array}{l}\text { To convert SI to U.S., } \\
\text { multiply by }\end{array}$ \\
\hline 29.5735 & $\mathrm{fl} \mathrm{oz}$ & $\mathrm{mL}$ & 0.0338 \\
0.3183 & $\mathrm{fl} \mathrm{oz} / \mathrm{ft}^{2}$ & $\mathrm{~L} \cdot \mathrm{m}^{-2}$ & 3.1414 \\
0.0929 & $\mathrm{ft}^{2}$ & $\mathrm{~m}^{2}$ & 10.7639 \\
2.54 & inch $(\mathrm{es})$ & $\mathrm{cm}$ & 0.3937 \\
25.4 & inch $(\mathrm{es})$ & $\mathrm{mm}$ & 0.0394 \\
6.4516 & inch & $\mathrm{cm}$ & 0.1550 \\
28,350 & $\mathrm{oz}$ & $\mathrm{mg}$ & $3.5274 \times 10^{-5}$ \\
305.1517 & $\mathrm{Oz} / \mathrm{ft}^{2}$ & $\mathrm{~g} \cdot \mathrm{m}^{-2}$ & 0.0033 \\
$\left({ }^{\circ} \mathrm{F}-32\right) \div 1.8$ & ${ }^{\circ} \mathrm{F}$ & ${ }^{\circ} \mathrm{C}$ & $\left({ }^{\circ} \mathrm{C} \times 1.8\right)+32$
\end{tabular}


established turfgrasses highlights the importance of rooting depth and density as factors contributing to drought avoidance (Carrow, 1996; Marcum et al., 1995; Miller and McCarty, 1998; Steinke et al., 2011). Busey (2003) reported that drought resistance in st. augustinegrass was likely not because of reduced evapotranspiration but rather because of wilt avoidance resulting from deeper and more extensive root systems. Huang and Gao (2000) examined developmental characteristics of roots of tall fescue (Lolium arundinaceum) and reported that a general root decline occurred in the upper $20 \mathrm{~cm}$ of soil as the drought stress ensued. However, drought-resistant cultivars in the study developed increased root length within the 40- to $60 \mathrm{~cm}$ depth, which reportedly aided plants by increasing water uptake from greater depths and compensated for decreased water uptake near the soil surface. Similar observations have been reported by Huang et al. (1997) as well as Sharp and Davies (1985) for warm-season turfgrasses and maize (Zea mays). To promote deeper and more extensive root systems, it has generally been recommended to increase the height of cut in managed turfgrass situations. As mowing height is reduced, the development of the root system is reduced through a root-shoot compensatory effect (Liu and Huang, 2002; Madison, 1962; Salaiz et al., 1995; Trenholm et al., 2000). Although increasing the mowing height during a $35-\mathrm{d}$ establishment period would likely encourage increased root development, withholding mowing altogether could conceivably produce even greater and more rapid benefits, so long as turf quality was not significantly sacrificed once mowing commenced at the end of the establishment period.

Less research has been focused on agronomic factors related to root development during early sod establishment. Amthor and Beard (2014) evaluated effects of transplant timing, receiving soil texture and moisture content, and nitrogen-phosphoruspotassium $(\mathrm{N}-\mathrm{P}-\mathrm{K})$ fertilizer amounts and placement (surface applied vs. soil incorporated) on root growth and anchoring strength of 'Tifgreen' hybrid bermudagrass (Cynodon dactylon $\times C$. transwaalensis) measured after $30 \mathrm{~d}$ of sod establishment. The authors reported that delaying sod harvest/ transplantation by 1 month after the end of shoot dormancy increased root anchoring strength $200 \%$ and root dry weight $640 \% 30 \mathrm{~d}$ after sodding. Furthermore, there was no effect of receiving soil moisture or $\mathrm{N}-\mathrm{P}-\mathrm{K}$ fertilizer amount or placement on sod root anchorage. Wherley et al. (2011) studied effects of cutting height and nitrogen application rate on root development of four warmseason turfgrasses during a 70-d establishment period in Florida. The authors reported that increasing $\mathrm{N}$ rates during establishment resulted in greater rates of root extension into deep soil; however, cutting height had no effect on root extension in three of the four species, including 'Floratam'. However, shorter mowing heights reduced total weight in all species during the establishment period.

PGRs are widely used in turf management for reducing shoot growth and frequency of mowing and/or seedhead suppression. TE is a commonly used PGR that reduces turfgrass shoot growth by inhibiting biologically active forms of gibberellins (King et al., 1997; Turgeon, 2002), but has shown little to no effect on seedhead suppression in st. augustinegrass (McCarty et al., 2004). TE has been shown to have little to no effect on photosynthesis (Qian et al., 1998) and to lead to reduced rates of maintenance respiration (Heckman et al., 2001). As such, it is believed that greater net photosynthesis may occur in TE-treated plants, with excess photosynthate not used for leaf elongation allocated to other organs (Ervin and Zhang, 2008). In fact, Fagerness et al. (2004) found that hybrid bermudagrass allocated 50\% more $\mathrm{N}$ with an atomic weight of 15 $\left({ }^{15} \mathrm{~N}\right)$-labeled ammonium nitrate to roots and rhizomes when treated with TE. This suggests that the altered allocation of nonstructural carbohydrates may promote greater rates of tillering, stem growth, or rooting during the period of TE suppression (Ervin and Zhang, 2008). Although it is currently labeled for use on a range of warm-season turfgrasses including st. augustinegrass, limited published information is available regarding the effects of $\mathrm{TE}$ on st. augustinegrass growth and development. Weinbrecht et al. (1998) reported the growth responses of st. augustinegrass to five commercial PGRs and noted that root length density was unaffected by PGR application. Information on the effects of TE application and mowing practices during early establishment of st. augustinegrass would be of interest to sod producers and turf managers as tools for potentially improving success of newly planted sod in the context of tight establishment timelines.

The objectives of this greenhouse study were to l) evaluate the effects of mowing and TE application on shoot growth, final turf quality, and root development characteristics (weight, total length, and extension rate) of st. augustinegrass sod during a 35-d establishment period, and 2) compare the quality and rooting potential of 'TamStar' and 'Floratam'.

\section{Materials and methods}

This research was conducted at the Texas A\&M University Department of Soil and Crop Science greenhouses in College Station, TX. The experiment was initiated on 4 Apr. 2012 (hereafter referred to as "study l") and repeated 29 May 2013 (hereafter referred to as "study 2 "), with each study lasting $35 \mathrm{~d}$. Greenhouse temperatures were set to $30 / 23{ }^{\circ} \mathrm{C}$ (day/night) temperatures for both studies. The greenhouse caused a $12 \%$ reduction in photosynthetic photon flux relative to ambient solar radiation. The study was arranged as a completely randomized block design with four replicates. A factorial arrangement with all possible combinations of cultivar (Floratam vs. TamStar), mowing (unmowed vs. mowed weekly at $6.3 \mathrm{~cm}$ ), PGR (no PGR vs. TE-applied at day 0 and day 21) was used. TE (Primo Maxx; Syngenta, Greensboro, NC) was applied to select treatments using a carbon dioxide $\left(\mathrm{CO}_{2}\right)$-powered backpack sprayer with XR Teejet 8002VS nozzles (Spraying Systems Co., Wheaton, IL) at $40 \mathrm{psi}$, at a rate of $28 \mathrm{mg} \cdot \mathrm{m}^{-2}$ a.i. diluted in $0.25 \mathrm{fl} \mathrm{oz} / \mathrm{ft}^{2}$ water. Applications were made immediately and $21 \mathrm{~d}$ after transplanting. During applications, non-PGR-treated plants were covered with paper bags to prevent off target movement of TE.

Plant materials of 'Floratam' and 'TamStar' were obtained from the Texas A\&M AgriLife Research, Dallas, TX. Six weeks before the start of 
study 1 , plugs were planted for both studies in 9 -inch ${ }^{2}$ pots using washed stolon segments (six single node stolons per pot). Stolons were allowed to establish into potting medium (Sunshine Mix; Sungro Horticulture, Bellevue, WA) and provided an initial fertilization using a $21 \mathrm{~N}-3.1 \mathrm{P}-11.6 \mathrm{~K}$ granular starter fertilizer (BCF Products, Greenville, TX) at a rate of $7.4 \mathrm{~g} \cdot \mathrm{m}^{-2} \mathrm{~N}$. Sprigged pots were watered twice daily, and trimmed twice weekly to $6.3 \mathrm{~cm}$ using scissors. After $\approx 4$ weeks, grasses had fully grown into pots with a complete root system developed.

Established plugs were then removed from pots, trimmed and washed free of soil to produce 9 -inch ${ }^{2}$ by 1 -inch-deep sod plugs. To initiate both studies, washed sod plugs were planted atop clear-walled, extruded acrylic plastic $\left(81 \mathrm{~cm}^{2}\right.$ by $90 \mathrm{~cm}$ deep) cylinders (Boedeker Plastics, Shiner, TX) filled with potting medium (Sunshine Mix) and capped at the base with a flat PVC endcap. Holes were drilled into the cap and covered with a l-inch pea gravel layer and screen to facilitate drainage. Efforts were made to uniformly tamp and saturate the potting soil before planting to prevent soil from settling during the experiment. Two layers of white polyester spandex material were used to encase the outside of the cylinders to prevent light penetration into the clear columns. The previously mentioned starter fertilizer was thoroughly mixed into the upper $10 \mathrm{~cm}$ of soil at a rate of $7.4 \mathrm{~g} \cdot \mathrm{m}^{-2} \mathrm{~N}$ just before planting sod pieces. During the initial week of both studies, $80 \mathrm{~mL}(1 \mathrm{~cm})$ of water was applied to each treatment on a daily basis. From weeks 2 to $5,175 \mathrm{~mL}(2.2 \mathrm{~cm})$ of irrigation was applied three times weekly.

Clippings from mowed treatments were collected weekly and trimmed at $6.3 \mathrm{~cm}$ during both studies using scissors and a ruler. Overhanging shoots and stolons extending beyond the perimeter of the column were also clipped and included in clipping samples. Clippings were oven dried at $65{ }^{\circ} \mathrm{C}$ for $72 \mathrm{~h}$ before being weighed. Visual quality assessments of each treatment were made on a weekly basis during the study immediately following mowing, rated on a scale from 1 to 9 with 1 = dead, 9 = best, and
$5=$ minimum acceptable quality. At the conclusion of the study, all treatments (including unmowed) were trimmed to $6.3 \mathrm{~cm}$, following which a final visual quality rating was then obtained for the previously unmowed treatments.

No seedheads became apparent during study 1 . However, during study 2 , seedhead production became apparent in the treatments, most notably in unmowed treatments. Therefore, seedhead production was visually evaluated during the final 2 weeks of study 2 . Seedhead evaluations were made on a 0 to 5 scale, with $0=$ no seedheads present and $5=$ high density of seedheads visible.

Weekly measurements of depth of maximal root extension were also noted within treatments similar to that previously reported by Wherley et al. (2011). Measurements were made by temporarily removing white polyester sleeves to expose the clear cylinder so that the depth of the two deepest roots could be measured and marked with tape on columns. These two readings were then averaged for each measurement date. Readings were recorded throughout the study or until two roots had reached the bottom of the cylinders. Data were then plotted over time to calculate rate of root extension for the treatments.

Following each $35-\mathrm{d}$ study, roots were removed from the cylinders and washed thoroughly to analyze total root length and root weight. Roots were divided into two categories, upper ( 2.5 to $45 \mathrm{~cm}$ depth) and lower (45- to $90-\mathrm{cm}$ depth) to allow for characterization of root development within shallow vs. deep soil depths. Total root length of these samples was measured using WinRhizo software (Regent Instruments, Quebec City, QC, Canada). Immediately after root length analysis was complete, the roots were dried at $65{ }^{\circ} \mathrm{C}$ for $72 \mathrm{~h}$ and then weighed.

Data for each parameter were subjected to analysis of variance (ANOVA) using the general linear model, univariate test procedure using SPSS (version 21.0; IBM Corp, Armonk, NY) to determine statistical significance of the results. Where ANOVA indicated a significant study effect, parameters were presented separately by study. Mean separation procedures were performed using
Fisher's least significant difference test at $P \leq 0.05$ level.

\section{Results and discussion}

Turfgrass visual Quality. Delaying mowing for $35 \mathrm{~d}$ did not reduce final turf quality relative to weekly mowed treatments in either study (Table 1 ). There was a cultivar $\times$ PGR interaction on visual quality at the conclusion of study 1 , although no differences in quality were observed for study 2 (Table 1; Fig. 1). TE application resulted in a lower final turf quality of 'Floratam', but had no effect on the quality of 'TamStar' (Fig. 1). Final visual quality ratings for 'Floratam' decreased from 7.9 to 6.9 because of TE application, whereas final quality of 'TamStar' exhibited a slight but nonsignificant increase from 8.4 to 8.8 following addition of TE. Weekly visual quality ratings of the cultivars taken during study $\mathrm{l}$ were consistent with final ratings, as 'TamStar' consistently exhibited slightly better quality over the 35-d period (darker color, higher density, and uniformity) as compared with 'Floratam' (data not shown).

The observation that TE application resulted in decreased quality in 'Floratam' in study $\mathrm{l}$ is consistent with the findings of McCarty et al. (2004), who reported that TE decreased visual quality in 'Floralawn' st. augustinegrass over a 5-week period in late June. However, by the completion of their 12-week study, both TE-treated and untreated 'Floralawn' exhibited similar visual quality ratings.

Clippings. Similar to visual quality, although numerous treatment effects and interactions were noted for study 1 , no differences were detected for study 2. During study 1 , there was a cultivar $\times$ PGR interaction on clipping dry weights (Fig. 2). TE application to 'TamStar' resulted in $47 \%$ (734 vs. $388 \mathrm{mg}$ ) reduction in clipping dry weight. Mean clipping reductions due to TE applications were less substantial in 'Floratam' (39\% reduction; 346 vs. $210 \mathrm{mg}$ ). Although no differences due to TE were observed in study 2 , there were again decreased clipping yields observed with the use of TE in both cultivars.

TE is commonly used on turfgrass to reduce mowing requirements. This occurs through inhibition of 


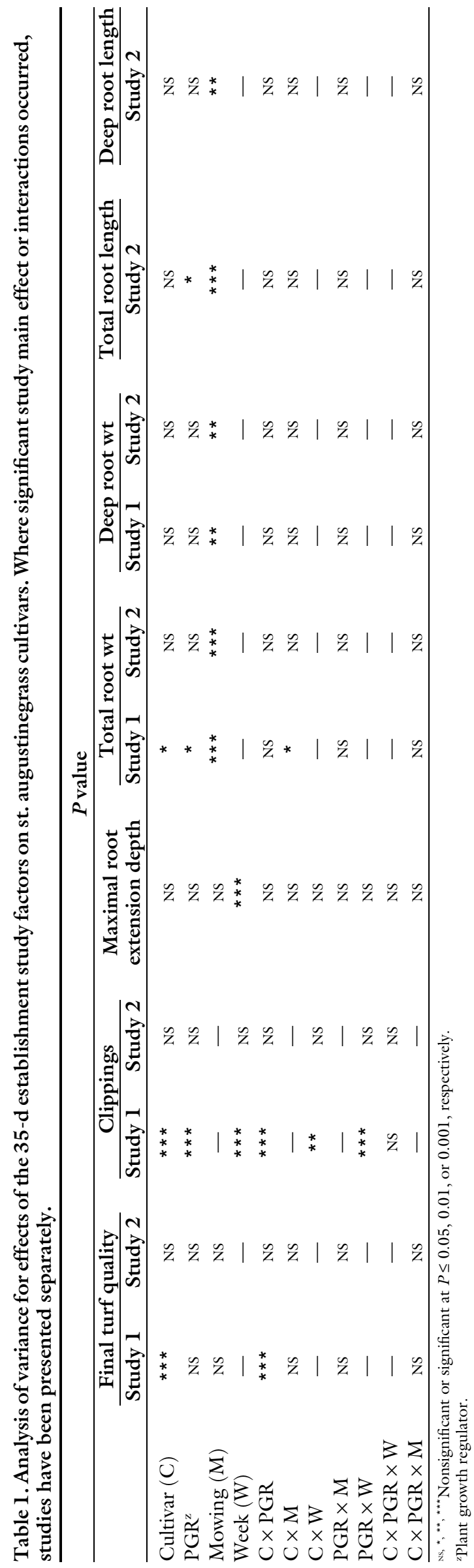

gibberellin acid synthesis, which reduces cell elongation and ultimately clipping yields and mowing frequency (Adams et al., 1992; Ervin and Koski, 2001; Fagerness and Penner, 1998). Our growth suppression data for st. augustinegrass for study 1 (39\% to $47 \%$ suppression) are consistent with McCarty et al. (2004), who reported that TE reduced clipping production by $50 \%$ on 'Floralawn'. The slightly lower levels of suppression we observed could be related to the relatively high amounts of irrigation that were applied for the newly establishing sod. The difference may also be attributed to the rate at which TE is metabolized by different cultivars, although further research would need to be conducted to confirm this.

There was a cultivar $\times$ week interaction on clippings in study 1 (Table 2). Rates of shoot growth for both cultivars dramatically increased over the 35-d period, from less than $100 \mathrm{mg} /$ week at week 1 to greater than $600 \mathrm{mg} /$ week by week 5 . 'TamStar' clippings were nearly twice those of 'Floratam' for each week, with the largest difference observed after week 3 , where average clipping weight of 'TamStar' was 2.5 times that of 'Floratam'. The apparent differences between cultivars may be related to morphological growth habit differences. Based on our observations, 'TamStar' appears to possess a denser and more upright growth habit compared with 'Floratam'. Cultivar differences in shoot growth rates have been previously noted within st. augustinegrass (Atkins et al., 1991).

A PGR $\times$ week interaction was also observed for clippings in study 1 (Table 2). Clipping weight increased weekly for plants not receiving TE application. However, in TE-treated plants, a rebound was observed at week 3. Although total clippings increased in both TE-treated and untreated plants, the level of growth suppression offered by the second TE application was less than that observed from the first application. Weinbrecht et al. (1998) reported st. augustinegrass growth suppression by TE of up to 4 weeks.

The overall reduced efficacy of $\mathrm{TE}$ in affecting clipping production and visual quality for study 2 may have been partially because of greater metabolism within the plant during 


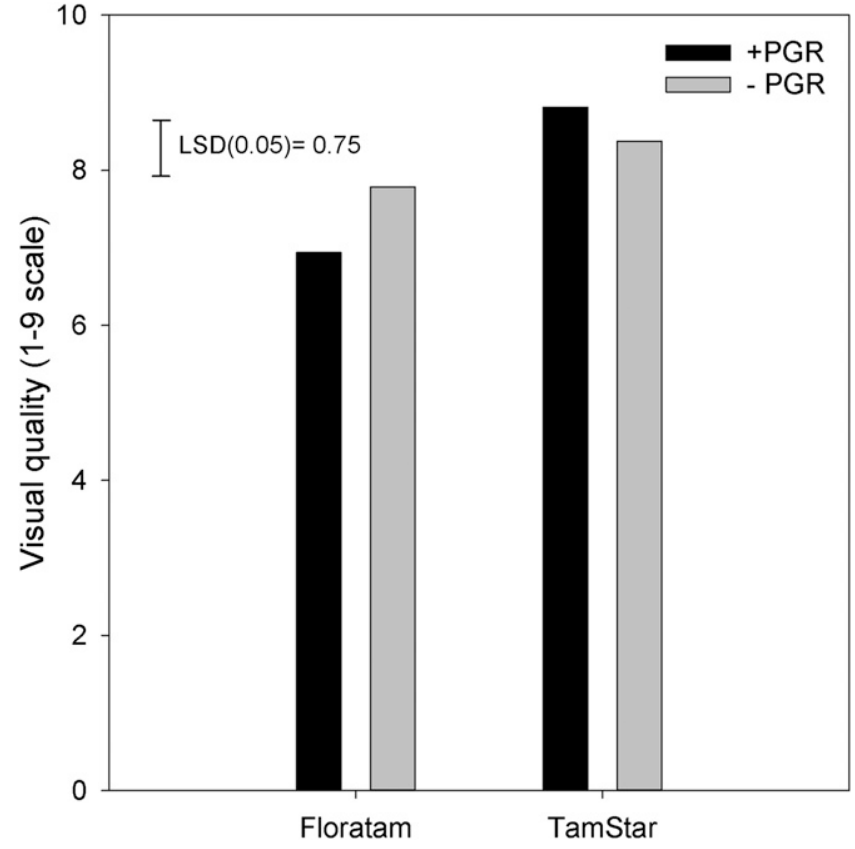

Fig. 1. Final turf quality ( $1=$ dead, $9=$ best, $5=$ minimum acceptable quality $)$ of 'Floratam' and 'TamStar' st. augustinegrass as influenced by application of plant growth regulator (PGR) and trinexapac-ethyl during 35-d establishment period for study 1. Data are pooled across mowing treatments. Error bar denotes least significant difference (LSD) at $P \leq 0.05$.

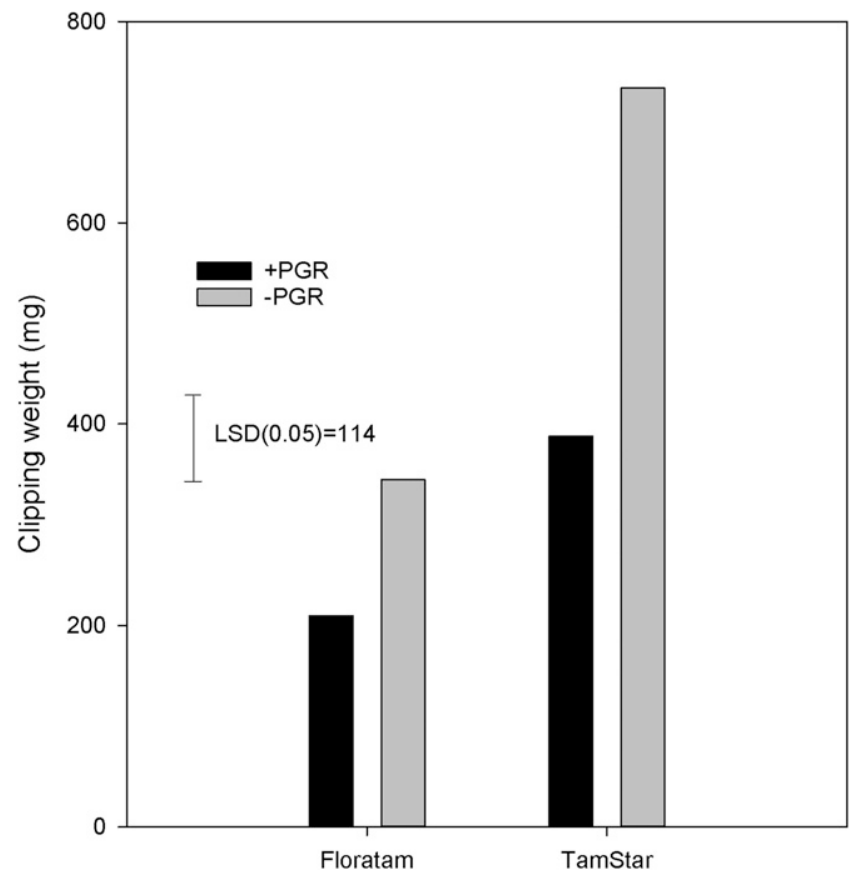

Fig. 2. Effect of plant growth regulator (PGR) and trinexapac-ethyl on mean weekly clipping dry weights of 'Floratam' and 'TamStar' st. augustinegrass during the 35-d establishment period for study 1 . Data are pooled across mowing treatments. Error bar denotes least significant difference (LSD) at $P \leq 0.05 ; 1 \mathrm{mg}=$ $3.5274 \times 10^{-5} \mathrm{oz}$.

the summer months (Beasley and Branham 2007; Kreuser and Soldat, 2011; Lickfeldt et al., 2001; Wherley and Sinclair, 2009). Although greenhouse temperatures for both studies were set to produce similar conditions, the longer days and more intense solar radiation of study 2 likely resulted in greater energy loading and plant temperatures. Furthermore, a developmental shift to reproductive seedhead development in plants was observed in all treatments midway into study 2 . Consistent with previous research on PGR-induced seedhead suppression (McCarty et al., 2004), we observed no suppression in seedhead numbers with TE application (data not shown). The fact that clipping collections included any growth (shoots and seedheads) occurring above a height of $6.3 \mathrm{~cm}$ apparently negated effects of TE on measured clippings during study 2 .

MAXIMAL ROOT EXTENSION DEPTH. Cultivar, mowing, and PGR treatments did not have any effect on depth of maximal root extension, and there were no differences detected between studies (Table 1). As such, only week main effect was found to be significant for rooting depth. Therefore, data were pooled across studies, cultivar, and treatment (Table 1). Average depth of the two deepest roots at the conclusion of the study approached $80 \mathrm{~cm}$ over the $35-\mathrm{d}$ period for both studies, resulting in an average root extension rate of about $2.3 \mathrm{~cm} \cdot \mathrm{d}^{-1}$ (Fig. 3). Turf having a deeper root system is more likely to survive periods of drought stress (Carrow, 1996; Marcum et al., 1995; Steinke et al., 2010, 2011). In a similar type of study, Wherley et al. (2011) found that st. augustinegrass, bahiagrass (Paspalum notatum), and zoysiagrass (Zoysia matrella) root extension rates during establishment were unaffected by mowing heights. The authors reported root extension rates between 1.0 and $1.8 \mathrm{~cm} \cdot \mathrm{d}^{-1}$, but also reported that increasing nitrogen fertility during establishment of these grasses resulted in accelerated root extension into deep soil for all species.

Root WeIgHT. Weekly mowing had a negative impact on total root weight measured at the conclusion of both studies. There was a cultivar $x$ mowing interaction on total root weight during study $\mathrm{l}$, and a mowing main effect detected for both studies (Table $\mathrm{l}$ ). Weekly mowing resulted in a decrease in total root weight for both cultivars (Table 3). For 'Floratam' and 'TamStar', $53 \%$ and $71 \%$ reductions in total root weight occurred because of weekly mowing. For study 2 , reductions in total root weight because of mowing were greater (about $85 \%$ reductions), 
Table 2. Cultivar and plant growth regulator (PGR) application effects on weekly clipping dry weights of st. augustinegrass during 35-d establishment period for study 1 .

\begin{tabular}{lccrr}
\hline & \multicolumn{2}{c}{ Cultivar $^{\mathbf{z}}$} & \multicolumn{2}{c}{ PGR $^{\mathbf{y}}$} \\
\cline { 2 - 5 } Week & \multicolumn{1}{c}{ Floratam } & TamStar & With PGR & Without PGR \\
\cline { 2 - 5 } 1 & $213 \mathrm{a}^{\mathrm{w}}$ & $106 \mathrm{~b}$ & $56 \mathrm{a}$ & $71 \mathrm{a}$ \\
2 & $64 \mathrm{a}$ & $251 \mathrm{~b}$ & $93 \mathrm{a}$ & $222 \mathrm{~b}$ \\
3 & $290 \mathrm{a}$ & $716 \mathrm{~b}$ & $400 \mathrm{a}$ & $606 \mathrm{~b}$ \\
4 & $361 \mathrm{a}$ & $705 \mathrm{~b}$ & $384 \mathrm{a}$ & $683 \mathrm{~b}$ \\
5 & $653 \mathrm{a}$ & $1,026 \mathrm{~b}$ & $563 \mathrm{a}$ & $1,116 \mathrm{~b}$ \\
\hline
\end{tabular}

${ }^{\mathrm{z}}$ Data are pooled across PGR treatments.

y Data are pooled across cultivars.

${ }^{\mathrm{x}} 1 \mathrm{mg}=3.5274 \times 10^{-5} \mathrm{oz}$

"Values within a given week and cultivar, or week and PGR, followed by the same letter do not differ at $P \leq 0.05$.

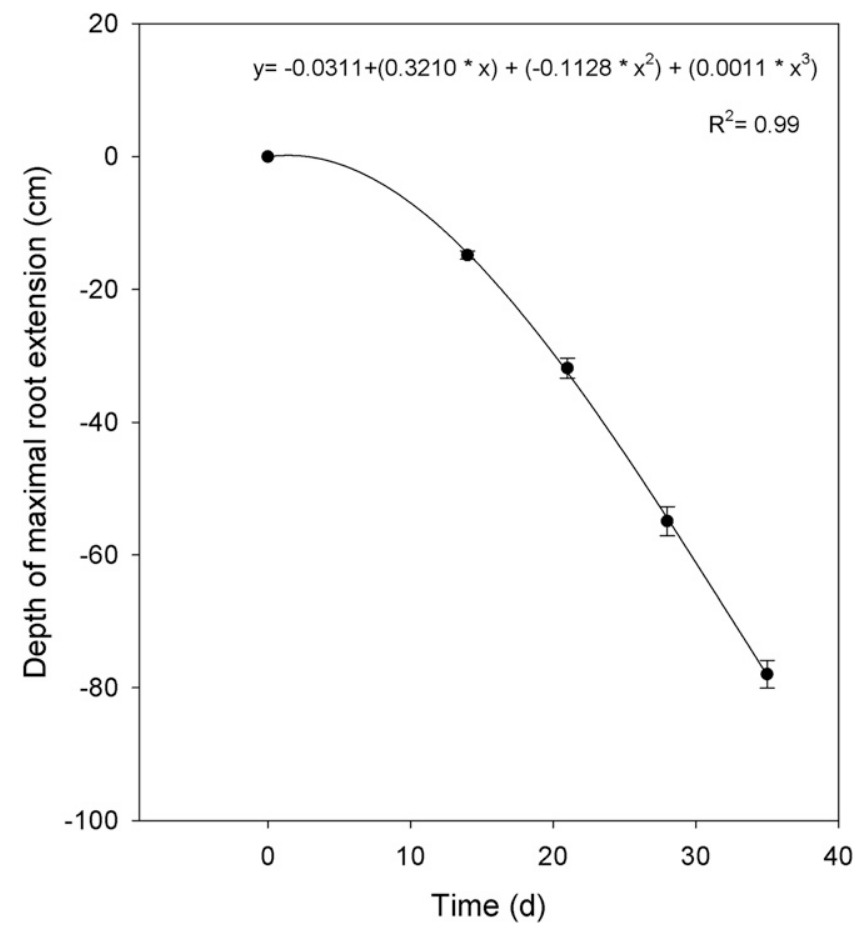

Fig. 3. Maximal root extension depth for two st. augustinegrass cultivars over the 35-d establishment period. Data are pooled across study, cultivars, and treatments. Error bars denote SE; $1 \mathrm{~cm}=0.3937$ inch .

Table 3. Effect of mowing frequency on total root weight of st. augustinegrass in the 2.5 - to $90-\mathrm{cm}(0.98$ to 35.43 inches $)$ depth during the $35-\mathrm{d}$ establishment period for study 1 .

\begin{tabular}{lccr}
\hline & \multicolumn{3}{c}{ Cultivar $^{\mathrm{z}}$} \\
\cline { 2 - 4 } Mowing frequency & Floratam & TamStar & Overall $^{\mathbf{y}}$ \\
\cline { 2 - 4 } Weekly & $711 \mathrm{a}^{\mathrm{w}}$ & Total root wt $(\mathbf{m g})^{\mathbf{x}}$ & $925 \mathrm{a}$ \\
Unmowed & $1,506 \mathrm{~b}$ & $22 \mathrm{a}$ & $6,353 \mathrm{~b}$ \\
\hline
\end{tabular}

${ }^{\mathrm{z}}$ Data are pooled across plant growth regulator (PGR) treatments.

y Data are pooled across both cultivars and PGR treatments.

${ }^{\mathrm{x}} \mathrm{l} \mathrm{mg}=3.5274 \times 10^{-5} \mathrm{oz}$.

walues within a given column followed by the same letter do not differ at $P \leq 0.05$.

but were similar between cultivars (Table 3).

Although total root weight is important, deep root production is arguably of greater importance in terms of drought resistance. A significant effect of weekly mowing on deep root weight $(45$ to $90 \mathrm{~cm})$ was observed in both studies, although greater differences between mowed and unmowed treatments occurred in study 2 (Fig. 4). Bonos and Murphy (1999) examined rooting responses of kentucky bluegrass (Poa pratensis) cultivars under summer heat/drought stress and found that the more drought-tolerant entries produced greater root weight at deeper soil depths (65\% greater root weight at 30 - to $45-\mathrm{cm}$ depth) compared with less intolerant entries. They also noted that within shallower $(0$ to $15 \mathrm{~cm})$ depths, stress-tolerant entries exhibited an $18 \%$ increase in root weight. Although mowing heights were not evaluated in their study, the results emphasize the benefits of increased root weight within deeper soil depths to heat and drought stress.

Although limited published data are available to compare rooting differences between mowed and unmowed turf, similar results were observed in terms of mowing height by Wherley et al. (2011), where greater total $(0$ to $90 \mathrm{~cm}$ ) and deep $(45$ to $90 \mathrm{~cm})$ root weight for st. augustinegrass, bahiagrass, zoysiagrass, and bermudagrass occurred with tall as opposed to short mowing heights. Although not measured under establishment conditions, similar results are reported for cool-season putting green turf. Fagerness and Yelverton (2001) reported that root biomass was $32 \%$ and $36 \%$ greater when cool-season 'Penncross' creeping bentgrass (Agrostis stolonifera) was maintained at a cutting height of 4.8 or $4.0 \mathrm{~mm}$ as opposed to $3.2 \mathrm{~mm}$.

TOTAL ROOT LENGTH EFFECTS. The effects of cultivar, mowing, and PGR applications on total root length are also of interest because increased root proliferation within soil contributes to more efficient absorption of water and nutrients during establishment. In our study, mowing caused effects on total root length $(2.5$ to 90 $\mathrm{cm}$ ) and deep root length (45 to 90 $\mathrm{cm}$ ) in study 2 (Table 1 ), but neither cultivar nor TE impacted root length in either study. Weekly mowing reduced both total root length $(20,433$ and $8,478 \mathrm{~cm}$ for unmowed and mowed, respectively) and deep root length (7513 and $3597 \mathrm{~cm}$ for unmowed and mowed, respectively) (Fig. 5). Qian et al. (1997) reported 
correlations between wilting of warm-season grass species and root length density within bermudagrass and zoysiagrass. Furthermore, PGRs such as TE inhibit gibberellin production and reduce cell elongation, and therefore, could conceivably influence elongation of both turfgrass shoots and roots. Carrow (1996) evaluated rooting responses to soil dry down in a range of warm- and cool-season grasses in Georgia and found the largest decrease in root length and density occurred in the top $10 \mathrm{~cm}$ of soil. In deeper (20- to $60-\mathrm{cm}$ depth) soil, total root length and density increased in 'Tifway' hybrid bermudagrass, common bermudagrass (Cynodon dactylon), 'Meyer' zoysiagrass (Zoysia japonica), centipedegrass (Eremochloa ophiuroides), 'Raleigh' st. augustinegrass, and 'Rebel II' and 'Kentucky-31' tall fescue during dry down. A relationship was noted between total root length within the deeper 20 - to $60-\mathrm{cm}$ soil depth and delayed leaf firing under drought stress. Interestingly, although 'Raleigh' st. augustinegrass was noted to have lower root length density than 'Tifway' bermudagrass within deep soil, it exhibited excellent tolerance to soil dry down with minimal leaf firing. This may suggest that rooting depth alone is as important a factor relating to drought resistance as root length density.

\section{Conclusions}

As municipal water restrictions become more commonplace across the United States, turf managers and homeowners will face challenges with shorter turfgrass establishment windows during water conservation periods. Thus, it has become increasingly important to examine cultural strategies for maximizing success during the early establishment period. A key component for long-term drought resistance in turfgrass is the development of a deep and extensive root system. In evaluating the effects of mowing and TE applications during this 35-d st. augustinegrass establishment period, we observed that weekly mowing reduced total and deep root weight as well as root length characteristics in both st. augustinegrass cultivars. Furthermore, although applications of TE slightly reduced turf quality in 'Floratam', and also resulted in

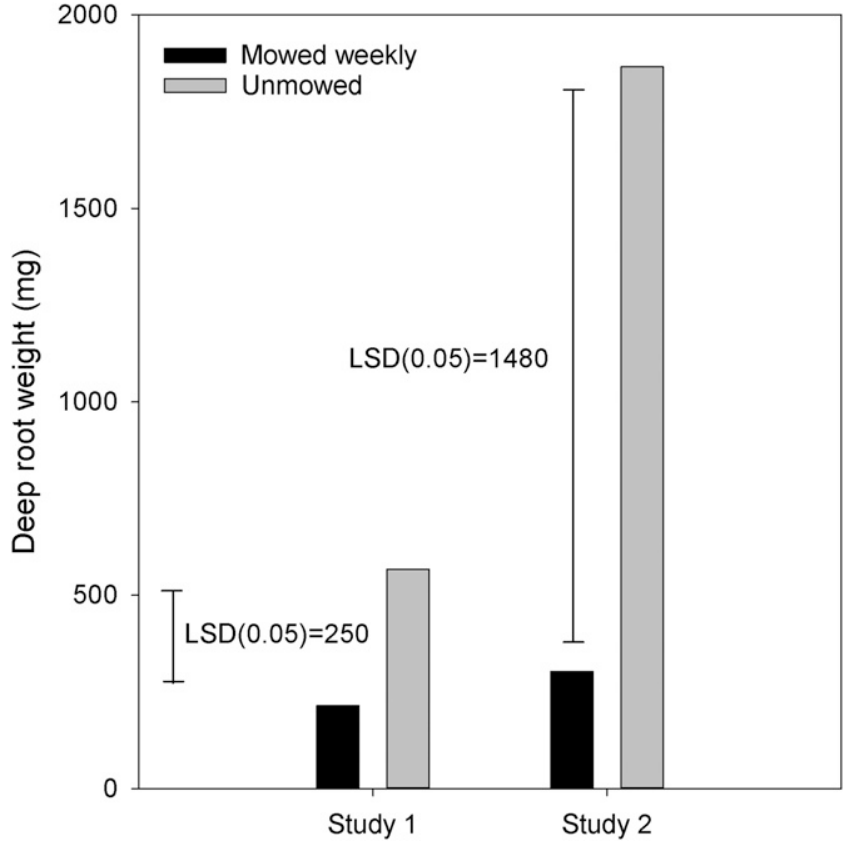

Fig. 4. Total root weight from the $45-$ to $90-\mathrm{cm}$ ( 17.72 to 35.43 inches) depth in st. augustinegrass at the conclusion of studies 1 and 2 as affected by weekly mowing vs. unmowed conditions during 35-d establishment period. Data are pooled across cultivar and plant growth regulator treatment. Error bars denote least significant difference (LSD) at $P \leq 0.05 ; 1 \mathrm{mg}=3.5274 \times 10^{-5} \mathrm{oz}$.

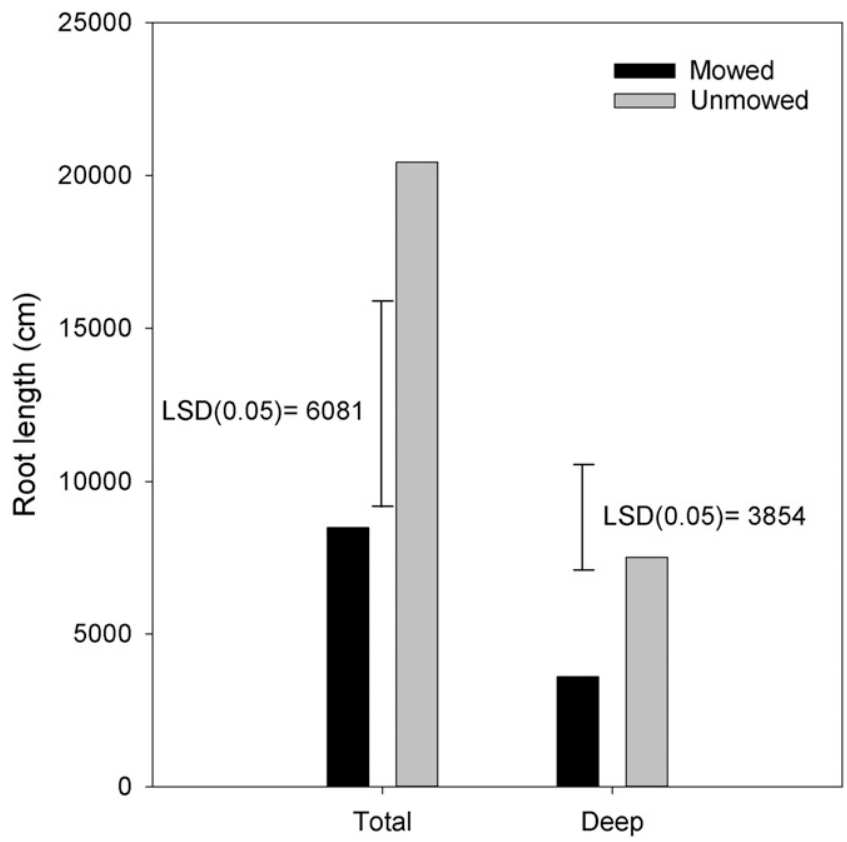

Fig. 5. Root length from the entire (total) $2.5-$ to $90-\mathrm{cm}$ soil depth and from the lower half (deep) $45-$ to $90-\mathrm{cm}$ soil depth as affected by weekly mowing vs. unmowed conditions during the 35-d establishment period for st. augustinegrass during study 2. Data are pooled across cultivars and plant growth regulator treatments. Error bars denote least significant difference (LSD) at $P \leq 0.05 ; 1 \mathrm{~cm}=$ 0.3937 inch.

reduced clipping yields in both cultivars, it failed to provide benefit in terms of root development for either cultivar. Neither mowing nor TE influenced depth of maximal root extension for either cultivar. 'TamStar' exhibited superior turf quality and root weight relative to the 'Floratam', 
but also generated higher amounts of cumulative shoot growth. Collectively, the results emphasize the importance of delaying mowing during st. augustinegrass establishment to promote enhanced root length and deep root production. Whether these short-term benefits observed under greenhouse conditions would translate to similar responses or improved drought resistance under subsequent mowing and water stress field conditions is a question that will require further investigation. Furthermore, this approach would likely require development of appropriate best management practice for reducing the mowing height of the grass that was unmowed during the establishment period.

\section{Literature cited}

Adams, R., E. Kerber, K. Pfister, and E.W. Weiler. 1992. Studies on the action of the new growth retardant CGA 163'935 (cimectacarb), p. 818-827. In: C.M. Karssen, L.C. van Loon, and D. Vreugdenhil (eds.). Progress in plant growth regulation. Springer-Verlag, New York, NY.

Amthor, J.S. and J.B. Beard. 2014. Root growth and anchorage by transplanted 'Tifgreen' (Cynodon dactylon x C. transvaalensis) turfgrass. Funct. Plant Biol. 41:276-286.

Atkins, C., R. Green, S. Sifers, and J. Beard. 1991. Evapotranspiration rates and growth characteristics of ten st. augustinegrass genotypes. HortScience 26:1488-1491.

Beasley, J.S. and B.E. Branham. 2007. Trinexapac-ethyl and paclobutrazol affect kentucky bluegrass single-leaf carbon exchange rates and plant growth. Crop Sci. 47:132-138

Bonos, S.A. and J.A. Murphy. 1999. Growth responses and performance of kentucky bluegrass under summer stress. Crop Sci. 39:770-774.

Busey, P. 1986. Morphological identification of st. augustinegrass cultivars. Crop Sci. 26:28-32.

Busey, P. 2003. St. augustinegrass, Stenotaphrum secundatum (Walter) Kuntze, p. 309-330. In: M.D. Casler and R.R. Duncan (eds.). Turfgrass biology, genetics, and breeding. Wiley, Hoboken, NJ.

Carrow, R.N. 1996. Drought resistance aspects of turfgrasses in the southeast: Root-shoot responses. Crop Sci. 36:687694.
Chandra, A., A. Genovesi, B. Wherley, S. Metz, J. Reinert, Y. Wu, P. Skulkaew, M. Engelke, D. Hargey, and L. Nelson. 2015. Registration of 'DALSA 0605' st. augustinegrass. J. Plant Registrations 9:27-34

Duble, R.L. 2013. St. augustine grass. 14 July 2015. <http://aggie-horticulture. tamu.edu/archives/parsons/turf/ publications/staug.html>.

Ervin, E.H. and A. Koski. 2001. Trinexapacethyl increases kentucky bluegrass leaf cell density and chlorophyll concentration. HortScience 36:787-789.

Ervin, E.H. and X. Zhang. 2008. Applied physiology of natural and synthetic plant growth regulators on turfgrasses, p. 171202. In: M. Pessarakli (ed.). Handbook of turfgrass management and physiology. CRC Press, Boca Raton, FL.

Fagerness, M.J. and D. Penner. 1998. Spray application parameters that influence the growth inhibiting effects of trinexapac-ethyl. Crop Sci. 38:1028-1035.

Fagerness, M.J. and F.H. Yelverton. 2001. Plant growth regulator and mowing height effects on seasonal root growth of penncross creeping bentgrass. Crop Sci. 41:1901-1905.

Fagerness, M.J., D.C. Bowman, F.H. Yelverton, and T.W. Rufty, Jr. 2004. Nitrogen use in Tifway bermudagrass as affected by trinexapac-ethyl. Crop Sci. 44:595-599.

Genovesi, A.D., R.W. Jessup, M.C. Engelke, and B.L. Burson. 2009. Interploid st. augustinegrass [Stenotaphrum secundatum (Walt.) Kuntze] hybrids recovered by embryo rescue. In Vitro Cell. Dev. Biol. Plant 45:659-666.

Heckman, N.L., T.E. Elthon, G.L. Horst, and R.E. Gaussoin. 2001. Influence of trinexapac-ethyl on respiration of isolated mitochondria. In: Annual Meetings Abstracts [CD-ROM]. Amer. Soc. Agron., Crop Sci. Soc. Amer., Soil Sci. Soc. Amer., Madison, WI.

Huang, B., R.R. Duncan, and R.N. Carrow. 1997. Drought-resistance mechanisms of seven warm-season turfgrasses under surface soil drying: II. Root aspects. Crop Sci. 37:1863-1869.

Huang, B. and H. Gao. 2000. Root physiological characteristics associated with drought resistance in tall fescue cultivars. Crop Sci. 40:196-203.

King, R.W., C. Blundell, L.T. Evans, L.N. Mander, and J.T. Wood. 1997. Modified gibberellins retard growth of cool-season turfgrasses. Crop Sci. 37:1878-1883.

Kreuser, W.C. and D.J. Soldat. 2011. A growing degree day model to schedule trinexapac-ethyl applications on Agrostis stolonifera golf putting greens. Crop Sci. 51:2228-2236.

Lickfeldt, D.W., D.S. Gardner, B.E. Branham, and T.B. Voigt. 2001. Implications of repeated trinexapac-ethyl applications on kentucky bluegrass. Agron. J. 93:1164-1168.

Liu, X. and B. Huang. 2002. Mowing effects on root production, growth, and mortality of creeping bentgrass. Crop Sci. 42:1241-1250.

Madison, J.H. 1962. Turfgrass ecology. Effects of mowing, irrigation, and nitrogen treatments of Agrostis palustris Huds., 'Seaside' and Agrostis temuis Sibth.,'Highland' on population, yield, rooting, and cover. Agron. J. 54:407-412.

Marcum, K.B., M. Engelke, S.J. Morton, and R.H. White. 1995. Rooting characteristics and associated drought resistance of zoysiagrasses. Agron. J. 87:534-538.

McCarty, L.B., J.S. Weinbrecht, J.E. Toler, and G.L. Miller. 2004. St. augustinegrass response to plant growth retardants. Crop Sci. 44:1323-1329.

Miller, G. and L. McCarty. 1998. Turfgrass rooting characteristics of 'Palmetto', 'FX-10', and 'Floratam' st. augustinegrasses and 'Pensacola' bahiagrass, $p$. 177-187. In: J.E. Box, Jr. (ed.). Root demographics and their efficiencies in sustainable agriculture, grasslands and forest ecosystems. Springer-Verlag, New York, NY.

Qian, Y.L., J.D. Fry, and W.S. Upham. 1997. Rooting and drought avoidance of warm-season turfgrasses and tall fescue in Kansas. Crop Sci. 37:905-910.

Qian, Y.L., M.C. Engelke, M.J.V. Foster, and S. Reynolds. 1998. Trinexapac-ethyl restricts shoot growth and improves quality of 'Diamond' zoysiagrass under shade. HortScience 33:1019-1022.

Salaiz, T., G. Horst, and R. Shearman. 1995. Mowing height and vertical mowing frequency effects on putting green quality. Crop Sci. 35:1422-1425.

San Antonio Water System. 2015. New landscape variance request. 15 July 2015. <http://www.saws.org/Conservation/ DroughtRestrictions/variance/request. cfm>.

Sharp, R. and W. Davies. 1985. Root growth and water uptake by maize plants in drying soil. J. Expt. Bot. 36:1441-1456.

Siefers, S. and J.B. Beard. 1999. Drought resistance in warm-season grasses. Golf Course Mgt. 67:67-70.

Southwest Florida Water Management District. 2015. Petition for variance or 


\section{Research Reports}

waiver. 15 July 2015. <https://www. swfwmd.state.fl.us/conservation/ restrictions/variance_petition.pdf>.

Steinke, K., D. Chalmers, J. Thomas, and R. White. 2011. Bermudagrass and buffalograss drought response and recovery at two soil depths. Crop Sci. 51:12151223.

Steinke, K., D. Chalmers, J. Thomas, R. White, and G. Fipps. 2010. Drought response and recovery characteristics of st. augustinegrass cultivars. Crop Sci. 50:2076-2083.
Trenholm, L., J. Cisar, and J.B. Unruh. 2000. St. augustinegrass for Florida lawns. Inst. Food Agr. Sci. Ext. Publ. ENH5.

Turgeon, A.J. 2002. Turfgrass management. Prentice Hall, Upper Saddle River, NJ.

Weinbrecht, J., L. McCarty, M. Kane, G. Miller, and G. Best. 1998. St. Augustinegrass root growth response following plant growth retardant application, p. 637650. In: J.E. Box, Jr. (ed.). Proc. Intl.
Soc. Root Res. Kluwer, Dordrecht, The Netherlands.

Wherley, B. and T.R. Sinclair. 2009. Growth and evapotranspiration response of two turfgrass species to nitrogen and trinexapac-ethyl. HortScience 44:20532057.

Wherley, B., T.R. Sinclair, M.D. Dukes, and A.K. Schreffler. 2011. Nitrogen and cutting height influence root development during warm-season turfgrass sod establishment. Agron. J. 103:16291634. 